Acta Cryst. (1986). B42, 639-640

\section{Prices of Acta Crystallographica and Journal of Applied Crystallography}

The Executive Committee of the International Union of Crystallography is pleased that it has not been necessary to increase the subscription rates and the prices of back numbers for Acta Crystallographica and Journal of Applied Crvstallography as from 1 January 1987.

\section{Acta Crystallographica}

The following rates will apply for Volumes A43, B43 and C43 (1987). All subscription rates are fixed in Danish kroner. The US dollar equivalents are no longer given because of rapid fluctuations in exchange rates.

Complete volumes, regular price per volume

Sections A, B \& C

(combined subscription)

Dkr 5250

Section A only

Dkr 1275

Section B only

Dkr 1275

Section C only

Dkr 3000

Complete volumes, reduced price for individuals

Sections A, B \& C (combined subscription)

Dkr 1450

Section A only

Section B only

Section C only

Dkr 350

Dkr 350

Dkr 850

All subscribers in the USA and Canada should add to the above subscription rates the additional charges for airfreighting as mentioned below.

The reduced-rate subscriptions are ordinarily only available to members of recognized scientific societies, and applications must be accompanied by a written undertaking that the journal is for the personal use of the subscriber and will not be made available to libraries, institutions, etc. These conditions also apply to persons wishing to order back numbers at the reduced rates.

Single parts

The price for single parts of any Section of Volume 43 (1987) is Dkr 320.

\section{Journal of Applied Crystallography}

The following rates will apply for Volume 20 (1987). All subscription rates are fixed in Danish kroner. The US dollar equivalents are no longer given because of rapid fluctuations in exchange rates.

Complete volumes, regular price per volume

Dkr 1275

Complete volumes, reduced price for individuals

Dkr 400

All subscribers in the USA and Canada should add to the above subscription rates the additional charge for airfreighting as mentioned below.

The same conditions apply to reduced-rate subscriptions as in the case of Acta Crystallographica (see above).
Single parts

The price for single parts of Volume 20 (1987) is Dkr 320.

\section{Airfreighting of copies to the USA and Canada}

Deliveries of Acta Crystallographica and Journal of Applied Crystallography to the USA and Canada in 1987 will continue to be by air freight to New York and thence by second class mail. The use of this service is obligatory for all subscribers in those countries. The charges in Danish kroner are as given below.

\section{Acta Crystallographica}

Sections A, B \& C

(combined subscription)

Section A only

Section B only

Section C only

Add Dkr 380

Add Dkr 90

Add Dkr 90

Journal of Applied Crystallography

Add Dkr 220

Add Dkr 70

\section{Prices of back numbers}

All these prices are fixed in Danish kroner. The US dollar equivalents are no longer given because of rapid fluctuations in exchange rates.

Acta Crystallographica

Complete volumes, regular price per volume

Vols. 1-23

Dkr 1275

Combined Vols. 24-38

Dkr 4600

Combined Vols. 39-42

Dkr 5250

Vols. A24-A42

Dkr 1275

Vols. B24-B38

Dkr 3500

Vols. B39-B42

Dkr 1275

Vols. C39-C42

Dkr 3000

Complete volumes, reduced price for individuals

Vols. 1-23

Dkr 350

Combined Vols. 24-38

Dkr 1300

Combined Vols. 39-42

Dkr 1450

Vols. A24-A42

Dkr 350

Vols. B24-B38

Dkr 1050

Vols. B39-B42

Dkr 350

Vols. C39-C42

Dkr 850

\section{Single parts}

Single parts of Volumes 1-23 are not available. The price of single parts of any Section of other Volumes is Dkr 320.

Cumulative Indexes, regular price

Vols. 11-23 (1958-1967)

Dkr 120

Vols. 24-28 (1968-1972)

Dkr 120

Vols. 29-38 (1973-1982)

Dkr 150

Cumulative Indexes, reduced price for individuals

Vols. 11-23 (1958-1967)

Vols. 24-28 (1968-1972)

Vols. 29-38 (1973-1982)

Dkr 60

Dkr 60

Dkr 75

A few copies of the cumulative index for Volumes 1-10 (1948-1957) are also available, free of charge. 
Journal of Applied Crystallography

Complete volumes, regular price per volume

Vols. 1-19

Dkr 1275

Complete volumes, reduced price for individuals

Vols. 1-19

Dkr 400

Single parts

The price for single parts of any volume is $\mathrm{Dkr} 320$.
Orders

Orders for Acta Cristallographica and Journal of Applied Crystallography may be addressed to Munksgaard International Publishers Ltd, 35 Nørre Søgade, DK-1370 Copenhagen K, Denmark. Orders from subscribers in North America may alternatively be placed through Polycrystal Book Service, PO Box 27, Western Springs, IL 60558, USA.

\section{Book Reviews}

Works intended for notice in this column should be sent direct to the Book-Review Editor (J. H. Robertson, School of Chemistry, University of Leeds, Leeds LS2 9JT, England). As far as practicable books will be reviewed in a country different from that of publication.

Acta Cryst. (1986). B42, 640

\section{Books Received}

The following books have been received by the Editor. Brief and generally uncritical notices are given of works of marginal crystallographic interest; occasionally a book of fundamental interest is included under this heading because of difficulty in finding a suitable reviewer without great delay.

Stereochemistry of organometallic and inorganic compounds. Edited by I. BERNAL. Pp. xii +451. Amsterdam: Elsevier, 1986. Price US \$101.75, Dfl 275.00.

Applications of NMR spectroscopy to problems in stereochemistry and conformational analysis. Edited by $\mathrm{Y}$. TAKEUCHI and A. P. MARChAND. Pp. ix + 221. Weinheim: VCH-Verlagsgesellschaft, 1986. Price DM 135.00, US $\$ 45.00$. Considering how immensely powerful X-ray diffraction is, for characterizing in detail the stereochemistry and conformation of molecules, it is important for crystallographers to be aware of the power that NMR spectroscopy now has in this area, and the extent to which its power is complementary to that of X-ray analysis.

Chemistry of organo-zirconium and organo-hafnium compounds. By D. J. CARDIN, M. F. LAPPERT and C. L. RASTON. Pp. 451. Chichester: Ellis Horwood, 1986. Price $£ 59.50$.

Biological and inorganic copper chemistry. Vols I and II. Edited by K. D. KARLIN and J. ZubieTA. Pp. xii +273, and xii +289 , respectively. Guilderland, New York: Adenine Press, 1986. Price US $\$ 65.00$ each volume.

Handbook on the physics and chemistry of rare earths. Vol. 8. Edited by K. A. GSCHEIDNER and L. EYRING. Pp. $\mathrm{X}+$ 382. Amsterdam: North-Holland, 1986. Price Dfl 240.00 . This is the latest of a continuing series which first appeared in 1978. For a review of Vols 1 and 2, see Kobyashi [ Acta Cryst. (1980), B36, 2861]. This volume, comprising chapters $54-57$, includes a very substantial survey of some 70 rareearth binary alloys, and also a long chapter on rare-earth inorganic complexes. 